J. Dairy Sci. 92:3791-3799

doi:10.3168/jds.2009-2151

(c) American Dairy Science Association, 2009.

\title{
Factors influencing variation of fatty acid content in ovine milk
}

\author{
L. F. De La Fuente, ${ }^{*}$ E. Barbosa, ${ }^{*}$ J. A. Carriedo, ${ }^{*}$ C. Gonzalo, ${ }^{* 1}$ R. Arenas, $†$ J. M. Fresno, $†$ \\ and F. San Primitivo* \\ *Departamento de Producción Animal, and \\ †Departamento de Higiene y Tecnología de los Alimentos, Facultad de Veterinaria, Universidad de León, 24071-León, Spain
}

\begin{abstract}
Between January 2006 and December 2007, a total of 4,579 test-day observations for contents of milk fatty acids (FA) were obtained from 2,218 lactations of 1,109 ewes belonging to 14 Churra dairy flocks. The 36 analyzed FA were quantified as grams per $100 \mathrm{~g}$ of total FA and were grouped as 18 dependent variables: 10 FA, 6 groups of FA, and 2 FA indexes. Flock, day of testing within flock (TD), ewe age, stage of lactation, and season effects contributed significantly to variations in FA. The 2 most important variation factors were flock ( 3 to $30 \%$ of total variance) and TD (35 to $70 \%$ of total variance). The percentage of variance explained by the TD effect for conjugated linoleic acid (CLA, C18:2 cis-9, trans-11) and linolenic acid (C18:3 cis-9, cis-12, cis-15) was particularly high: 60.7 and $68.2 \%$, respectively. The season effect was also a very important variation factor, closely linked to feeding. The most significant seasonal variations were observed in polyunsaturated FA, with the highest values occurring in spring and summer and the lowest in winter. More specifically, CLA and linolenic acid contents were 44 and 30\% higher in spring-summer than in winter. As the age of the ewe increased, the monounsaturated and polyunsaturated FA decreased and the short- and medium-chain saturated FA increased. The CLA and the CLA/C18:1 trans-11 $\Delta^{9}$-desaturase index increased significantly throughout lactation. The correlation coefficient between rumenic acid (CLA) and vaccenic acid was high (0.47) because of the precursor-product relationship via the $\Delta^{9}$-desaturase enzyme. The correlation coefficients were high between C10:0 and C12:0 (0.79), C12:0 and C14:0 (0.73), and C14:0 and C16:0 (0.29), probably because of their similar metabolic origin. Positive correlations were also obtained among the $\mathrm{C}_{18} \mathrm{FA}$ family. All the studied factors of FA variation would be considered as fixed effects in the statistical models used
\end{abstract}

Received February 20, 2009.

Accepted April 21, 2009.

${ }^{1}$ Corresponding author: c.gonzalo@unileon.es for estimation of genetic and phenotypic parameters from test-day records of commercial flocks.

Key words: fatty acid, conjugated linoleic acid, variation factor, dairy ewe

\section{INTRODUCTION}

Ovine milk is important in Mediterranean countries, some of which have well-established complete or simplified milk-recording schemes. Normal husbandry in these countries traditionally includes a lamb-suckling period of approximately $1 \mathrm{mo}$ and an intensive milking period after weaning. In Spain, ovine milk represents $5 \%$ of national milk production (cow, sheep, and goat species), and this percentage is $20 \%$ in the CastillaLeón region, where the Churra breed lives. Ewe milk is a product that is high in fat and protein and is mainly used for commercial or artisanal cheeses, with the mean consumption of cheese in several Mediterranean countries being greater than $20 \mathrm{~kg}$ per person and year. As a result, other components of milk, such as fatty acids (FA), could be considered. Indeed, FA in milk are becoming more and more important because of the link between the FA content in the diet and certain illnesses. Anticarcinogenic and antiatherogenic properties have been attributed to the conjugated linoleic acid (CLA) C18:2 cis-9, trans-11 isomer (rumenic acid; Lee et al., 2005; Bauman et al., 2006; Soyeurt and Gengler, 2008). Linolenic acid (C18:3 cis-9, cis-12, cis-15) is also of interest in cardiovascular problems (Metka et al., 2006; Mesa et al., 2007), and other FA have been related to human health because of their monounsaturated or polyunsaturated nature. As a result, research is currently being carried out on the FA content of ruminant milk in different areas, such as genetic improvement (Bobe et al., 2008; Carta et al., 2008; Soyeurt and Gengler, 2008), food (Metka et al., 2006; Gómez-Cortés et al., 2008; Tsiplakou and Zervas, 2008), and other sources of variation. However, there is very little information on factors that influence variations in FA content in commercial flocks of dairy sheep. In these types of flock, the main sources of variation in milk composition variables, such as fat, protein, and 
CN content or SCC count, have been studied by several authors (Gonzalo et al., 1994; El-Saied et al., 1998; Othmane et al., 2002b). The variation factors studied by these authors have been flock, lactation stage, age of ewe, parity number, and day of testing within each flock (TD). This latter effect is associated with actual circumstances (feeding, environment, management) of the flock on the day of testing. El-Saied et al. (1998) and Othmane et al. (2002a) included those variation factors in the mathematical models used for genetic parameter estimation from test-day records in dairy sheep. For FA, lactation stage (Peterson et al., 2002; Kelsey et al., 2003; Kay et al., 2005) and parity effects (Cranix et al., 2008) in dairy cattle have been studied by several authors. Similarly, Stoop et al. (2008) analyzed the herd effect, linked to feeding and management, in cow milk, and Chilliard et al. (2003) discussed the importance of season as a factor for polyunsaturated FA (PUFA) in goat milk, with this seasonal effect being associated with fresh grass feeding in spring and summer. For the FA content of dairy cow milk, Soyeurt et al. (2006, 2007) used mathematical models from test-day records of commercial herds to study the differences between breeds and to estimate genetic parameters. These models included the effects of flock, TD, parity number, and lactation stage. In this sense, an attempt should be made to study these variation factors in depth, because they are used in the estimation of phenotypic and genetic parameters of FA content. In addition, flock, season, and TD are factors influenced by feeding and handling, whereas parity and lactation stage have a physiological component. Nevertheless, no research has been carried out on how these factors influence variations in FA content in commercial ewe flocks.

We hypothesized that these variation factors would be of interest to include in the statistical models used for estimation of genetic and phenotypic parameters of FA, as well as to evaluate specific physiological effects (i.e., age and lactation stage) on FA composition of milk in commercial ewe flocks. To test these hypotheses, the present study was carried out to analyze the following sources of variation in FA content: flock, TD, season, age of ewe, and lactation stage in dairy ewe flocks. Additionally, the correlation coefficients between FA were estimated. Within the FA considered, variations in CLA and linolenic acid were particularly emphasized.

\section{MATERIALS AND METHODS}

\section{Data Collection}

A total of 4,579 test-day observations for contents of 36 FA were obtained from 2,218 lactations of 1,109 ewes belonging to 14 Churra dairy flocks for 2 con- secutive years. Although this was an observational study, the design was established to study the fixed variation factors that could be included in statistical models used for the estimation of genetic and phenotypic parameters of milk FA. In most cases, at least 2 test-day records were collected from each ewe in each of 2 consecutive lactations. Individual milk samples (50 $\mathrm{mL}$ ) were taken between January 2006 and December 2007 for the National Association of Spanish Churra Breeders (Palencia, Spain). The data recorded were flock, animal, date of sampling throughout $2 \mathrm{yr}$ of sampling, age of animal, parity, and stage of lactation (days postpartum). Samples were preserved with bronopol $(0.05 \%)$ and stored at $4^{\circ} \mathrm{C}$ until laboratory analysis within $96 \mathrm{~h}$ after collection. The analytical determination of $36 \mathrm{FA}$ per sample was carried out in the dairy plant of the Department of Animal Production and the Food Technology Department of León University, León, Spain. The 14 flocks were on the alternative a.m.p.m. plan of National Association of Spanish Churra Breeders testing. This simplified procedure is based on monthly recording of only 1 daily milking: a.m. or p.m, which is suggested in ovine milk recording for practical and economic reasons (International Committee for Animal Recording, 1992; Gonzalo et al., 2003). The first test-day record was obtained at least $3 \mathrm{~d}$ after the lambs had been weaned. The suckling period was between 20 and $35 \mathrm{~d}$ postpartum. All ewes were milked twice daily during the milking period. Churra ewes are permanently housed in winter and are fed preserved forage and cereals, including alfalfa and grass hay, barley, corn (Zea mays), and soybeans. In contrast, sheep graze in spring and summer, with fresh grass forage and cereal stubble added to the previously mentioned diet. Nevertheless, feeding regimen variations in each flock were not recorded because such variations were not the objective of this study. Overall, parities took place continuously throughout the year and lactations were uniformly distributed.

\section{Fatty Acid Analysis}

Lipids of milk samples were extracted by the method of Bligh and Dyer (1959) using chloroform and methanol. The chloroform layer containing lipids was passed through anhydrous sodium sulfate $\left(\mathrm{Na}_{2} \mathrm{SO}_{4}\right)$ and was concentrated by nitrogen evaporation. Lipid extracts were stored at $-30^{\circ} \mathrm{C}$ until further analysis.

Fatty acids methyl esters (FAME) were prepared by base-catalyzed methanolysis of the glycerides $\left(\mathrm{NaOCH}_{3}\right)$ according to the method of Aldai et al. (2005). Undecanoic acid (C11:0) was added as internal standard. The FAME were analyzed on a Hewlett-Packard chromatograph (model 6890, Hewlett-Packard, Wilmington, 
DE) equipped with an automatic injector (model 7683, Hewlett-Packard) and a mass selective detector (model 5973, Hewlett-Packard). The FAME were separated using a Tekno TR-CN 100 capillary column $(60 \mathrm{~m} \times$ $0.25 \mathrm{~mm}$ i.d. $\times 0.20-\mu \mathrm{m}$ film thickness; Teknokroma, Barcelona, Spain). Helium was used as a carrier gas at a flow rate of $1 \mathrm{~mL} / \mathrm{min}$. The injection and detector temperatures were $230^{\circ} \mathrm{C}$. The temperature program was as follows: the initial temperature was held at $50^{\circ} \mathrm{C}$ for $1 \mathrm{~min}$ after injection, then programmed to increase at $15^{\circ} \mathrm{C} / \mathrm{min}$ to $200^{\circ} \mathrm{C}$, held there for $3 \mathrm{~min}$, and then programmed to increase at $2^{\circ} \mathrm{C} / \mathrm{min}$ to $220^{\circ} \mathrm{C}$, and held there for $5 \mathrm{~min}$. Samples $(1 \mu \mathrm{L})$ were injected by split injection (split ratio 10:1).

Identification of FAME was performed from the retention times by using standards of methyl esters. A mixture of the standards of 37 individual FAME (Supelco, Bellefonte, PA) was used to determine response factors. The peak areas in the chromatogram were calculated and normalized using response factors. The individual FA contents were expressed as weight percentages $(\mathrm{g} / 100 \mathrm{~g}$ of total FA).

\section{Dependent Variables for the Study of Variation Factors}

Although 36 FA were initially determined analytically, the statistical study of the variation factors was restricted to the most important $10 \mathrm{FA}, 6$ groups of FA, and $2 \mathrm{FA}$ indexes, all of which were treated as dependent variables. The groups, which were based on the saturation level and chain length, were as follows: sum of saturated FA (SFA), sum of short-chain saturated FA $\left(\mathrm{C}_{4}\right.$ to $\mathrm{C}_{10}$, SCFA), sum of medium-chain saturated FA $\left(\mathrm{C}_{12}\right.$ to $\mathrm{C}_{15}$, MCFA $)$, and sum of long-chain saturated FA $\left(\mathrm{C}_{16}\right.$ to $\mathrm{C}_{24}$, LCFA). The 2 remaining groups were the sum of monounsaturated FA (MUFA) and the sum of PUFA. One of the 2 indexes considered was the ratio of unsaturated FA, resulting from dividing the sum of unsaturated FA (UNSFA multiplied by 100) by SFA (UNSFA $\times 100 /$ SFA). The other index related rumenic and vaccenic FA (C18:2 cis-9, trans-11 × 100/ C18:1 trans-11). The criteria for selecting the $10 \mathrm{FA}$ as dependent variables were as follows: 1) considering the 7 quantitatively most important FA, with percentages above $3.5 \%$ (Arenas et al., 2007), and 2) including 3 additional FA of biological interest, which were CLA, vaccenic acid, and linolenic acid.

\section{Statistical Analysis}

Statistical analysis was carried out based on a mixed model, with ewe as the random factor, using the MIXED procedure of SAS (release 9.1; SAS Institute, 1997) and following the mathematical model below:

$$
\mathrm{Y}_{\mathrm{ijk} k m n}=\mu+\mathrm{F}_{\mathrm{i}}+\mathrm{TD}_{\mathrm{j}(\mathrm{i})}+\mathrm{L}_{\mathrm{k}}+\mathrm{A}_{\mathrm{l}}+\mathrm{E}_{\mathrm{m}(\mathrm{i})}+\varepsilon_{\mathrm{ijk} k m n},
$$

where $Y_{\mathrm{ijklmn}}$ refers to the 18 dependent variables; that is, $10 \mathrm{FA}, 6$ groups of FA, and $2 \mathrm{FA}$ indexes. The factor $\mathrm{TD}_{\mathrm{j}(\mathrm{i})}$ refers to the fixed effect of TD. Contemporary groups were formed on the basic test date; there were 157 levels for the TD factor. The day of testing was considered throughout the 2-yr period when samples were taken. The factor $L_{k}$ refers to the fixed effect of lactation stage; there were 6 levels: 1 to 6 mo postpartum. The factor $A_{1}$ refers to the fixed effect of age of ewe; there were 5 categories for age of ewe (ages $1 \mathrm{yr}$ to $\geq 5 \mathrm{yr}$ ). The age of ewe and parity number factors are closely correlated in dairy sheep, so generally only one of them is included in the mathematical models. The factor $E_{m(i)}$ refers to the random effect of ewe within flock (1,109 levels), and the factor $\varepsilon_{\mathrm{ijk} k \mathrm{mn}}$ is the residual effect.

The MIXED procedure was used to study the statistical significance of the variation factors, and the least squares means and contrasts of differences between means were estimated. Following the indicated model, but considering all factors as random, the VARCOMP procedure was used to estimate the REML variance component of the factors, to quantify the percentage of variance explained by each one.

Additionally, a second mathematical model was followed to study the season variation factor. This factor was not included in the first model because the $T D_{j(i)}$ factor included, among other effects, part of the information on season. The second model had the same factors as the first one, but the $\mathrm{TD}_{\mathrm{j}(\mathrm{i})}$ factor was replaced by the season fixed effect $\left(\mathrm{S}_{\mathrm{j}}\right)$. The seasons considered were winter (mo 1, 2, and 3), spring (mo 4, 5, and 6), summer (mo 7, 8, and 9) and autumn (mo 10, 11, and 12).

\section{RESULTS AND DISCUSSION}

\section{Descriptive Statistics}

The descriptive statistics for the contents of the 36 analyzed FA, 6 groups of FA (SFA, SCFA, MCFA, LCFA, MUFA, and PUFA), and 2 FA indexes (UNSFA/ SFA and C18:2 cis-9, trans-11/C18:1 trans-11) studied are shown in Table 1.

High SFA $(71.35 \%)$ and LCFA $(36.32 \%)$ contents and low MUFA $(22.10 \%)$ and PUFA $(6.54 \%)$ contents were observed in ovine milk (Table 1). Two additional groups of FA were added for discussion: FA with a relatively high content $(>3.50 \%)$ in milk, and FA of particular interest in food for human consumption, but with a low content. Some of the SFA, such as palmitic (C16:0, $22.04 \%)$, stearic $(\mathrm{C} 18: 0,10.50 \%)$, capric $(\mathrm{C} 10: 0,8.61 \%)$, 
Table 1. Descriptive statistics for composition of the 36 fatty acids, 6 groups of fatty acids, and 2 fatty acid indexes for Churra ewe milk from 4,579 test-day records

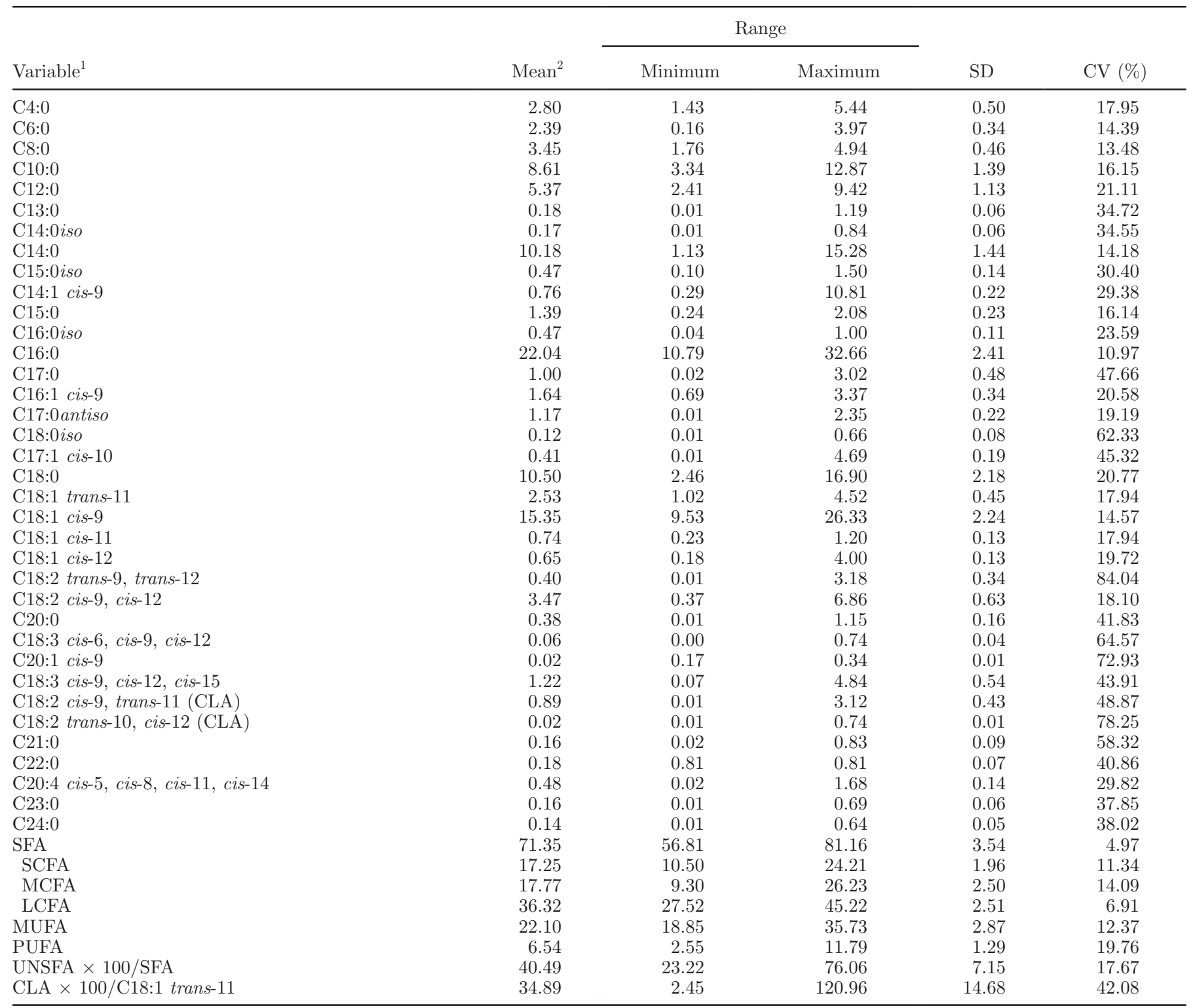

${ }^{1} \mathrm{CLA}=$ conjugated linoleic acid; SFA = sum of saturated fatty acids; SCFA = sum of short-chain saturated fatty acids; $\mathrm{MCFA}=$ sum of medium-chain saturated fatty acids; LCFA = sum of long-chain saturated fatty acids; MUFA = sum of monounsaturated fatty acids; PUFA = sum of polyunsaturated fatty acids; UNSFA $=$ sum of unsaturated fatty acids.

${ }^{2}$ Grams per $100 \mathrm{~g}$ of total fatty acids.

lauric (C12:0, 5.37\%), and myristic (C14:0, 10.18\%) acids had a relatively high content in milk (Table 1). Similarly, the contents of oleic acid (C18:1 cis-9, $15.35 \%)$ and linoleic acid (C18:2 cis-9, cis-12, 3.47\%) were high. For most of these variables, the results were consistent with those obtained by Carta et al. (2008) in dairy sheep, Soyeurt et al. (2006, 2007) and Soyeurt and Gengler (2008) in dairy cattle, and Metka et al. (2006) in goats. The CLA C18:2 cis-9, trans-11 isomer is of great interest in food for human consumption (Lee et al., 2005; Soyeurt and Gengler, 2008) and had a higher content $(0.89 \%)$ than the CLA C18:2 trans-10, cis-12 isomer $(0.02 \%)$. Concentrations of vaccenic acid $(2.53 \%)$ and linolenic acid $(1.22 \%)$ were higher than concentrations of CLA.

\section{Flock and TD Within-Flock Effects}

Table 2 shows the percentage of variance explained by sources of variation for the $10 \mathrm{FA}, 6$ groups, and 
Table 2. Percentage of variance explained by each fixed effect for the 10 fatty acids, 6 groups of fatty acids, and 2 fatty acid indexes considered

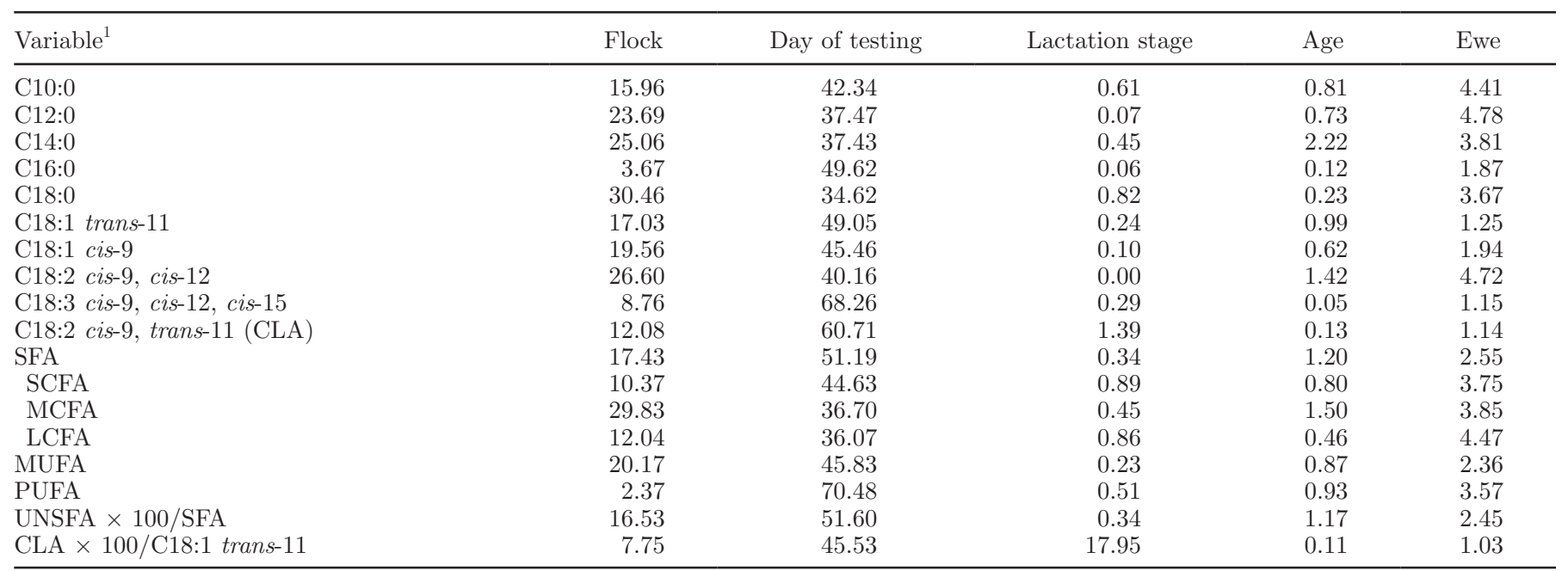

${ }^{1} \mathrm{CLA}=$ conjugated linoleic acid; SFA = sum of saturated fatty acids; SCFA = sum of short-chain saturated fatty acids; MCFA = sum of medium-chain saturated fatty acids; LCFA = sum of long-chain saturated fatty acids; MUFA $=$ sum of monounsaturated fatty acids; PUFA $=$ sum of polyunsaturated fatty acids; UNSFA = sum of unsaturated fatty acids.

2 indexes. According to the percentage of variance explained, flock and TD were the 2 most important sources of variation for the 18 dependent variables. The percentage of variance explained by the flock effect was between 10 and $30 \%$ for most of the dependent variables. This fact was evidence of an important variability among flocks in FA content because of feeding and management differences in ewe commercial flocks. In this sense, there were considerable differences among flocks with regard to how long the grazing and housing periods lasted, the types of pastures for grazing, and the feed regimens during housing. These results were in accordance with those obtained in dairy cattle by Stoop et al. (2008), which estimated very high percentages of variance explained by the herd factor for 16 FA, including rumenic and linolenic acids. Similarly, for other milk composition variables, such as percentages of fat and protein, Gonzalo et al. (1994) found significant differences among Churra ewe flocks.

The TD factor was the most important of all the studied effects because it explained 35 to $70 \%$ of the variance for the 18 variables considered. This factor is associated with the actual circumstances of the flock on the day of testing within each flock, particularly with feeding and, to a lesser extent, with other management factors. Thus, the TD factor also included the season variation factor and explained the high variability in FA contents throughout the year within each flock. The percentage of variance explained by the TD factor was particularly high for CLA and linolenic acid: 60.7 and $68.2 \%$, respectively, as shown in Table 2. For milk composition variables (fat, protein, and $\mathrm{CN}$ content), other authors (El-Saied et al., 1998; Othmane et al., $2002 \mathrm{~b}$ ) also found the TD effect to be a very significant variation factor in the Churra breed. The importance of 2 previously mentioned factors (flock and TD) was related to the high variance explained by the mathematical model $\left(\mathrm{R}^{2}\right)$ for the 18 variables studied (54 to $79 \%)$.

\section{Lactation Stage and Age of Ewe Effects}

For the $10 \mathrm{FA}$ and 6 groups of FA studied, the percentage of variance explained by lactation stage and age of ewe was lower than 1.4 and $2.3 \%$, respectively (Table 2 ). This indicated that both factors were quantitatively of much less importance than the flock and TD effects. Nevertheless, these factors could undoubtedly be of biological interest, but there is little information on their effect in dairy sheep. Our results on the percentage of variance explained by lactation stage and ewe age were in accordance with those obtained for both factors by Kelsey et al. (2003) for FA in dairy cattle. Lactation stage and ewe age had a significant effect on most FA. Least squares means of the 10 FA, 6 groups, and 2 indexes by age of ewe, as well as the statistical significance of this effect, are shown in Table 3. The ewe age effect was significant in 5 of the 6 groups of FA. As the age of ewes increased, the SCFA and MCFA increased significantly (Table 3 ), and this increase was accompanied by a decrease $(P<0.001)$ in the MUFA and PUFA contents (Table 3). The most important differences were for the ewes aged $1 \mathrm{yr}$. Specifically, the FA family represented by C10:0, C12:0, and C14:0, 
Table 3. Least squares means and standard errors for fatty acid content by age of ewe in dairy sheep

\begin{tabular}{|c|c|c|c|c|c|c|c|c|}
\hline Variable $^{1,2}$ & \multicolumn{5}{|c|}{ Age (yr) } & $\mathrm{SE}$ & Evolution & $P$-value \\
\hline C10:0 & $8.43^{\mathrm{c}}$ & $8.82^{\mathrm{a}}$ & $8.78^{\mathrm{ab}}$ & $8.80^{\mathrm{ab}}$ & $8.71^{\mathrm{b}}$ & 0.04 & Increase & $* * *$ \\
\hline C14:0 & $9.96^{\mathrm{c}}$ & $10.38^{\mathrm{b}}$ & $10.34^{\mathrm{b}}$ & $10.39^{\mathrm{b}}$ & $10.57^{\mathrm{a}}$ & 0.03 & Increase & $* * *$ \\
\hline C16:0 & $22.13^{\mathrm{ab}}$ & $22.05^{\mathrm{b}}$ & $22.06^{\mathrm{b}}$ & $22.22^{\mathrm{ab}}$ & $22.36^{\mathrm{a}}$ & 0.07 & & * \\
\hline $\mathrm{C} 18: 0$ & $10.81^{\mathrm{a}}$ & $10.48^{\mathrm{b}}$ & $10.49^{\mathrm{b}}$ & $10.58^{\mathrm{b}}$ & $10.56^{\mathrm{b}}$ & 0.06 & Decrease & $* *$ \\
\hline C18:3 cis-9, cis- 12 , cis- 15 & $1.20^{\mathrm{a}}$ & $1.19^{\mathrm{a}}$ & $1.20^{\mathrm{a}}$ & $1.16^{\mathrm{b}}$ & $1.16^{\mathrm{b}}$ & 0.01 & Decrease & $* *$ \\
\hline C18:2 cis-9, trans-11 (CLA) & $0.86^{\mathrm{a}}$ & $0.86^{\mathrm{a}}$ & $0.85^{\mathrm{ab}}$ & $0.82^{\mathrm{b}}$ & $0.82^{\mathrm{b}}$ & 0.01 & Decrease & ** \\
\hline SFA & $71.17^{\mathrm{c}}$ & $71.94^{\mathrm{b}}$ & $71.88^{\mathrm{b}}$ & $72.12^{\mathrm{a}}$ & $72.23^{\mathrm{a}}$ & 0.08 & Increase & $* * *$ \\
\hline SCFA & $17.04^{\mathrm{b}}$ & $17.56^{\mathrm{a}}$ & $17.51^{\mathrm{a}}$ & $17.50^{\mathrm{a}}$ & $17.43^{\mathrm{a}}$ & 0.05 & Increase & $* * *$ \\
\hline MCFA & $17.42^{\mathrm{b}}$ & $18.15^{\mathrm{a}}$ & $18.09^{\mathrm{a}}$ & $18.14^{\mathrm{a}}$ & $18.25^{\mathrm{a}}$ & 0.06 & Increase & $* * *$ \\
\hline LCFA & $36.70^{\mathrm{a}}$ & $36.22^{\mathrm{b}}$ & $36.28^{\mathrm{b}}$ & $36.48^{\mathrm{ab}}$ & $36.55^{\mathrm{a}}$ & 0.07 & & $* * *$ \\
\hline
\end{tabular}

${ }^{\mathrm{a}-\mathrm{d}}$ Means in the same row with different superscripts differ $(P<0.05)$.

${ }^{1} \mathrm{CLA}=$ conjugated linoleic acid; SFA = sum of saturated fatty acids; SCFA = sum of short-chain saturated fatty acids; MCFA = sum of medium-chain saturated fatty acids; LCFA $=$ sum of long-chain saturated fatty acids; MUFA $=$ sum of monounsaturated fatty acids; PUFA $=$ sum of polyunsaturated fatty acids; UNSFA $=$ sum of unsaturated fatty acids.

${ }^{2}$ Grams per $100 \mathrm{~g}$ of total fatty acids.

${ }^{3}$ Number of test-day records.

${ }^{*} P<0.05 ;{ }^{* *} P<0.01 ;{ }^{* * *} P<0.001$.

which are synthesized de novo by the ewe, increased $(P$ $<0.001$ ) with the age of ewes (Table 3 ), whereas the C18 FA family, such as linoleic, rumenic, stearic, oleic, vaccenic, and linolenic acids, decreased $(P<0.01)$ as the ewe age increased. On the contrary, for FA in dairy cattle, Cranix et al. (2008) did not find any significant influence of the parity effect, so further studies in other breeds of milking ewes would be needed to corroborate our results and to establish their physiological or metabolic meaning.

Table 4 shows the least squares means of the 18 dependent variables and their statistical significance by the lactation stage effect. In general terms, the percentage of variance explained by the lactation factor for the FA considered was low. As shown in Table 4, CLA increased progressively $(P<0.001)$ by $18 \%$, from 0.78 (mo 1) to $0.92 \%$ (mo 6), but the percentage of variance explained by this effect was relatively low: $1.4 \%$ (Table $2)$. For the CLA $\times 100 / \mathrm{C} 18: 1$ trans-11 index, there was also a progressive increase $(P<0.001)$ of $20 \%$ throughout lactation: from 30.9 (mo 1) to 37.1 (mo 6; Table 4 ), with the percentage of variance explained for this index being very high: $17.9 \%$ (Table 2). These results are in accordance with the increases in CLA and the CLA/C18:1 trans-11 index during lactation observed in dairy cattle by several authors (Kelsey et al., 2003; Kay et al., 2005; Garnsworthy et al., 2006); however, other authors (Peterson et al., 2002) obtained small differences in rumenic acid and in $\Delta^{9}$-desaturase activity during the lactation or did not find CLA variation by lactation stage in dairy cattle (Chichlowski et al., 2005). Because the CLA/C18:1 trans- 11 index is an important indicator of $\Delta^{9}$-desaturase enzyme activity in endogenous synthesis of CLA (Peterson et al., 2002), our results seem to indicate an increase of CLA and the CLA/C18:1 trans-11 $\Delta^{9}$-desaturase index throughout lactation in dairy sheep.

\section{Season Effect}

Table 5 shows the least squares means of the 10 FA, 6 groups, and 2 indexes studied, and also their statistical significance by the season factor. The season effect was statistically significant for the 18 dependent variables considered. The most important variations were for PUFA, with the highest values occurring in spring and summer and the lowest in winter (Table 5). The variation in SCFA and MCFA, although less marked, was inverse to that of PUFA. These variations were in accordance with feeding. Thus, ewes were housed and fed on preserved forage and cereals in winter, whereas in spring and summer, ewes were grazing fresh grass forage and cereal stubble during most of the day. With regard to feeding and handling, autumn is a season of 
Table 4. Least squares means and standard errors for fatty acid content by lactation stage in dairy sheep

\begin{tabular}{|c|c|c|c|c|c|c|c|c|c|}
\hline Variable $^{1,2}$ & \multicolumn{6}{|c|}{ Month of lactation (postpartum) } & $\mathrm{SE}$ & Evolution & $P$-value \\
\hline C10:0 & $8.73^{\mathrm{b}}$ & $8.88^{\mathrm{a}}$ & $8.87^{\mathrm{a}}$ & $8.65^{\mathrm{ab}}$ & $8.63^{\mathrm{bc}}$ & $8.54^{\mathrm{c}}$ & 0.04 & Decrease & $* * *$ \\
\hline C14:0 & $10.12^{\mathrm{c}}$ & $10.25^{\mathrm{b}}$ & $10.34^{\mathrm{a}}$ & $10.34^{\mathrm{a}}$ & $10.36^{\mathrm{a}}$ & $10.33^{\mathrm{a}}$ & 0.05 & Increase & $* * *$ \\
\hline C16:0 & $22.25^{\mathrm{a}}$ & $22.24^{\mathrm{a}}$ & $22.09^{\mathrm{ab}}$ & $21.93^{\mathrm{b}}$ & $21.74^{\mathrm{b}}$ & $22.03^{\mathrm{ab}}$ & 0.09 & & NS \\
\hline C18:0 & $11.00^{\mathrm{a}}$ & $10.69^{\mathrm{b}}$ & $10.51^{\mathrm{c}}$ & $10.47^{\mathrm{c}}$ & $10.41^{\mathrm{c}}$ & $10.47^{\mathrm{c}}$ & 0.07 & Decrease & $* * *$ \\
\hline $\mathrm{C} 18: 2$ cis- 9 , cis- 12 & $3.52^{\mathrm{a}}$ & $3.50^{\mathrm{a}}$ & $3.49^{\mathrm{a}}$ & $3.51^{\mathrm{a}}$ & $3.52^{\mathrm{a}}$ & $3.50^{\mathrm{a}}$ & 0.02 & & NS \\
\hline $\mathrm{C} 18: 3$ cis-9, cis- 12 , cis- 15 & $1.13^{\mathrm{c}}$ & $1.14^{\mathrm{c}}$ & $1.19^{\mathrm{b}}$ & $1.22^{\mathrm{ab}}$ & $1.24^{\mathrm{ab}}$ & $1.24^{\mathrm{a}}$ & 0.01 & Increase & ** \\
\hline $\mathrm{C} 18: 2$ cis -9, trans -11 (CLA) & $0.78^{\mathrm{d}}$ & $0.81^{\mathrm{cd}}$ & $0.82^{\mathrm{c}}$ & $0.87^{\mathrm{b}}$ & $0.89^{\mathrm{ab}}$ & $0.92^{\mathrm{a}}$ & 0.01 & Increase & $* * *$ \\
\hline SFA & $72.07^{\mathrm{ab}}$ & $72.27^{\mathrm{a}}$ & $72.02^{\mathrm{b}}$ & $71.57^{\mathrm{c}}$ & $71.39^{\mathrm{c}}$ & $71.57^{\mathrm{c}}$ & 0.10 & Decrease & $*$ \\
\hline SCFA & $17.60^{\mathrm{b}}$ & $17.78^{\mathrm{a}}$ & $17.61^{\mathrm{b}}$ & $17.29^{\mathrm{c}}$ & $17.27^{\mathrm{c}}$ & $17.19^{\mathrm{c}}$ & 0.08 & Decrease & $* *$ \\
\hline MCFA & $17.65^{\mathrm{c}}$ & $17.93^{\mathrm{b}}$ & $18.11^{\mathrm{a}}$ & $18.11^{\mathrm{a}}$ & $18.15^{\mathrm{a}}$ & $18.07^{\mathrm{a}}$ & 0.08 & Increase & $* * *$ \\
\hline LCFA & $36.81^{\mathrm{a}}$ & $36.57^{\mathrm{b}}$ & $36.31^{\mathrm{c}}$ & $36.17^{\mathrm{c}}$ & $35.97^{\mathrm{c}}$ & $36.31^{\mathrm{c}}$ & 0.10 & Decrease & $* * *$ \\
\hline
\end{tabular}

${ }^{\mathrm{a}-\mathrm{d}}$ Means in the same row with different superscripts differ $(P<0.05)$.

${ }^{1} \mathrm{CLA}=$ conjugated linoleic acid; SFA $=$ sum of saturated fatty acids; SCFA = sum of short-chain saturated fatty acids; MCFA = sum of medium-chain saturated fatty acids; LCFA = sum of long-chain saturated fatty acids; MUFA = sum of monounsaturated fatty acids; PUFA = sum of polyunsaturated fatty acids; UNSFA = sum of unsaturated fatty acids.

${ }^{2}$ Grams per $100 \mathrm{~g}$ of total fatty acids.

${ }^{3}$ Number of test-day records.

${ }^{*} P<0.05 ;{ }^{* *} P<0.01 ; * * P<0.001$.

transition. Thus, in autumn the contents of the FA and FA groups were, in most cases, between those corresponding to winter and spring-summer. The CLA and linolenic acid contents increased by 44 and 30\%, respectively, from winter to spring-summer (Table 5), which indicates the importance of the feeding effect on the content of these FA. These results were also observed by Chilliard et al. (2003) in dairy sheep, cattle, and goats. These authors related the season effect to the consumption of fresh grass, which is associated with increased contents of CLA and linolenic acid in milk. Variations between winter and spring-summer were of quantitatively little importance for MUFA and the C18:0 saturated FA.

One last source of variation included in the mathematical model was the random ewe effect. The relative importance of this factor is shown in Table 2, where the percentage of variance explained by the ewe effect for the studied variables was quantified. For the specific conditions of Churra ewes and the types of flocks considered in this study, the percentage of variance explained by the ewe factor was low for the studied FA (Table 2). Results obtained by Carta et al. (2008) in an experimental flock of dairy sheep and by Soyeurt et al. (2006, 2007) and Bobe et al. (2008) in dairy cattle showed a high relative importance of the animal factor for most FA and groups of FA. The high within-flock variability in feeding and handling conditions in the commercial Churra flocks studied would explain the low relative importance of the sheep factor that we found.

\section{Correlations Between Milk FA}

Table 6 shows the Pearson correlation coefficients between the $10 \mathrm{FA}$ considered, of the 36 total FA. Correlations between FA groups were not studied because FA were expressed as a percentage of the total FA and because the number of FA groups was small. Two FA families were considered: FA between C10:0 and C16:0 versus the C18 FA family. The correlations were positive between the FA within each group and negative between each other. These values would be biologically interpreted (Bobe et al., 1999; Chilliard et al., 2003; Bauman et al., 2006) and explained by similarities in their origin, that is, synthesis de novo versus passed from the blood to the milk. In this sense, the correlation coefficients were higher between FA with a similar number of carbons; thus, between $\mathrm{C} 10: 0$ and $\mathrm{C} 12: 0$ (0.79), C12:0 and C14:0 (0.73), and C14:0 and C16:0 (0.29), the correlations were high and positive, which can be explained by the similarity of their metabolic origin. In contrast, the correlation between C16:0 and C18:0 FA, which have a different origin, was negative $(-0.31)$. Relatively high correlation coefficients between 
Table 5. Least squares means and standard errors for fatty acid content by season in dairy sheep

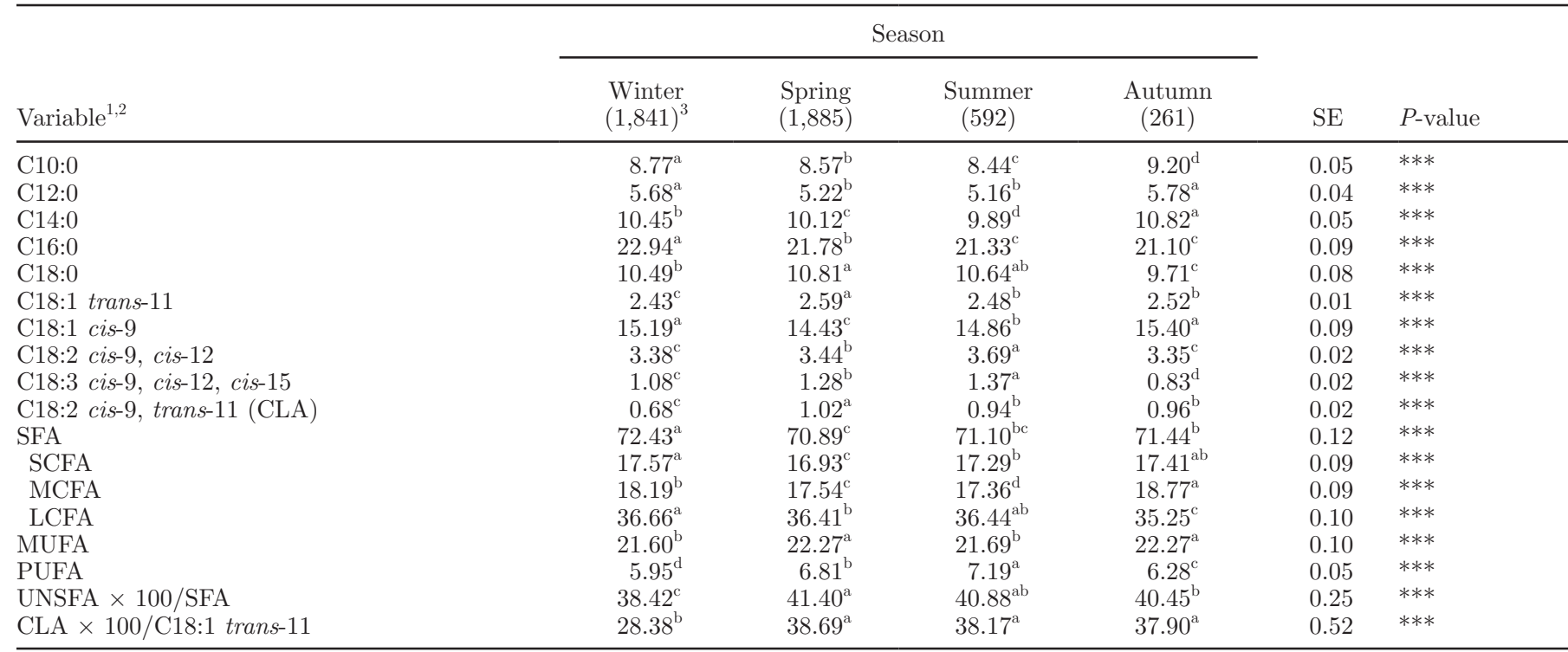

${ }^{\mathrm{a}-\mathrm{d}}$ Means in the same row with different superscripts differ $(P<0.05)$.

${ }^{1}$ CLA $=$ conjugated linoleic acid; SFA = sum of saturated fatty acids; SCFA = sum of short-chain saturated fatty acids; MCFA = sum of medium-chain saturated fatty acids; LCFA = sum of long-chain saturated fatty acids; MUFA = sum of monounsaturated fatty acids; PUFA = sum of polyunsaturated fatty acids; UNSFA = sum of unsaturated fatty acids.

${ }^{2}$ Grams per $100 \mathrm{~g}$ of total fatty acids.

${ }^{3}$ Number of test-day records.

$* * * P<0.001$.

C18:0 and linoleic, oleic, and vaccenic acids, of 0.30 , 0.37 , and 0.38 , respectively, were also obtained. As a whole, the correlation coefficients reported in this study were consistent with those found by Chilliard et al. (2003). A high correlation $(\mathrm{r}=0.47)$ was also obtained between CLA and vaccenic acid, in accordance with the correlation (0.61) found by Peterson et al. (2002) in dairy cattle. These authors attributed this correlation to the precursor-product relationship for endogenous synthesis via the $\Delta^{9}$-desaturase enzyme.

\section{CONCLUSIONS}

Flock, TD, lactation stage, age of ewe, and season had a significant effect on FA content in dairy sheep milk. The 3 quantitatively most important sources of variation in FA content were the flock, season, and TD factors. The most important variations related to TD and season effects occurred in rumenic (CLA) and linolenic acids. These $2 \mathrm{FA}$ were higher in spring-summer than in winter.

Lactation stage and age of ewe had a significant effect on some FA. As the age of ewe increased, MUFA and PUFA decreased and SCFA and MCFA increased. The most important differences were for ewes aged 1 yr. Lactation stage increased the CLA and the CLA/ C18:1 trans-11 $\Delta^{9}$-desaturase index in dairy sheep. The correlation coefficient between rumenic and vaccenic acids was high because of the precursor-product relationship. Finally, the variation factors studied would be

Table 6. Pearson correlation coefficients between the 10 main fatty acids in dairy sheep (expressed as g/100 g of total fatty acids)

\begin{tabular}{|c|c|c|c|c|c|c|c|c|c|}
\hline Variable & $\mathrm{C} 12: 0$ & C14:0 & C16:0 & C18:0 & $\begin{array}{c}\mathrm{C} 18: 1 \\
\text { trans-11 }\end{array}$ & C18:1 cis-9 & $\begin{array}{c}\mathrm{C} 18: 2 \text { cis- } 9 \\
\text { cis- } 12\end{array}$ & $\begin{array}{l}\mathrm{C} 18: 3 \text { cis- } 9 \\
\text { cis- } 12, \text { cis }-15\end{array}$ & $\begin{array}{c}\mathrm{C} 18: 2 \text { cis- } 9, \\
\text { trans-11 (CLA) }\end{array}$ \\
\hline C10:0 & 0.79 & 0.64 & 0.13 & -0.51 & -0.65 & -0.65 & -0.22 & -0.25 & -0.28 \\
\hline $\mathrm{C} 12: 0$ & & 0.73 & 0.09 & -0.56 & -0.66 & -0.61 & -0.20 & -0.28 & -0.37 \\
\hline C16:0 & & & & -0.31 & -0.26 & -0.51 & -0.29 & -0.29 & -0.30 \\
\hline C18:0 & & & & & 0.38 & 0.37 & 0.30 & 0.04 & -0.03 \\
\hline C18:1 trans -11 & & & & & & 0.62 & 0.12 & 0.21 & 0.47 \\
\hline C18:3 cis- 9, cis- 12, cis- 15 & & & & & & & & & 0.29 \\
\hline
\end{tabular}

${ }^{1} \mathrm{CLA}=$ conjugated linoleic acid. 
considered as fixed effects in the statistical models used for estimation of genetic and phenotypic parameters of FA from test-day records of commercial flocks.

\section{ACKNOWLEDGMENTS}

This work was supported by the Spanish Ministry of Science (Madrid, Spain; project AGL2005-04321) and the Castilla and Leon regional government (Junta de Castilla y León, Valladolid, Spain) by a grant for research groups of excellence (project GR43).

\section{REFERENCES}

Aldai, N., B. E. Murray, A. I. Nájera, D. J. Troy, and K. Osoro. 2005. Derivatization of fatty acids and its application for conjugated linoleic acid studies in ruminant meat lipids. J. Sci. Food Agric. 85:1073-1083.

Arenas, R., E. Barbosa, B. Prieto, F. San Primitivo, J. M. Fresno, and L. F. De La Fuente. 2007. Variaciones temporales del contenido de ácidos grasos de leche de oveja. Pages 201-204 in IV Jornadas Ibéricas de razas autóctonas y sus productos tradicionales, 2007, Sevilla, Spain. Publ. Junta de Andalucía, Sevilla, Spain

Bauman, D. E., I. H. Mather, R. J. Wall, and A. L. Lock. 2006. Major advances associated with the biosynthesis of milk . J. Dairy Sci. 89:1235-1243.

Bligh, E. G., and W. J. Dyer. 1959. A rapid method of total lipid extraction and purification. Can. J. Biochem. Physiol. 37:911917.

Bobe, G., D. C. Beitz, A. E. Feeman, and G. L. Lindberg. 1999 Associations among individual proteins and fatty acids in bovine milk as determined by correlations and factor analyses. J. Dairy Res. 66:523-536.

Bobe, G., J. A. Minick Bormann, G. L. Lindberg, A. E. Freeman, and D. C. Beitz. 2008. Estimates of genetic variation of milk fatty acids in US Holstein cows. J. Dairy Sci. 91:1209-1213.

Carta, A., S. Casu, M. G. Usai, M. Addis, M. Fiori, A. Fraghí, S Miari, L. Mura, G. Piredda, L. Schibler, T. Sechi, J. M. Elsen, and F. Barillet. 2008. Investigating the genetic component of fatty acids content in sheep milk. Small Rumin. Res. 79:22-28.

Chichlowski, M. W., J. W. Schoeder, C. S. Park, W. L. Keller, and D. E. Schimek. 2005. Altering the fatty acids in milk fat by including canola seed in dairy cattle diets. J. Dairy Sci. 88:3084-3094.

Chilliard, Y., A. Ferlay, J. Rouel, and G. Lambere. 2003. A review of nutritional and physiological factors affecting goat milk synthesis and lipolysis. J. Dairy Sci. 86:1751-1770.

Cranix, M.,, A. Steen, H. Van Laar, T. Van Nespen, J. Martín-Teroso, B. De Baets, and V. Fievez. 2008. Effect of lactation stage on the odd- and branched-chain milk fatty acids of dairy cattle under grazing and indoor conditions. J. Dairy Sci. 91:2662-2677.

El-Saied, U. M., J. A. Carriedo, and F. San Primitivo. 1998. Heritability of test day somatic cell counts and its relationship with milk yield and protein percentage in dairy ewes. J. Dairy Sci. 81:29562961.

Garnsworthy, P. C., L. L. Masson, A. L. Lock, and T. T. Mottram. 2006. Variation of milk citrate with stage of lactation and de novo fatty acid synthesis in dairy cows. J. Dairy Sci. 89:1604-1612.
Gómez-Cortés, P., P. Frutos, A. R. Mantecón, M. Juarez, M. A. de la Fuente, and G. Hervás. 2008. Addiction of olive oil to dairy ewe diets: Effect on milk fatty acid profile and animal performance. J. Dairy Sci. 91:3119-3127.

Gonzalo, C., J. A. Carriedo, J. A. Baro, and F. San Primitivo. 1994. Factors influencing variation of test day milk yield, somatic cell count, fat, and protein in dairy sheep. J. Dairy Sci. 77:15371542.

Gonzalo, C., M. H. Othmane, J. A. Fuertes, F. De La Fuente, and F. San Primitivo. 2003. Losses of precision associated with simplified designs of milk recording for dairy ewes. J. Dairy Res. 70:441444 .

International Committee for Animal Recording. 1992. Regulations for milk recording in dairy sheep. Group of Experts for Milk Recording in Dairy Sheep, Eur. Assoc. Anim. Prod., Rome, Italy.

Kay, J. K., W. J. Weber, C. E. Moore, D. E. Bauman, L. B. Hansen, H. Chester-Jones, B. A. Crooker, and L. H. Baumgard. 2005. Effects of week of lactation and genetic selection for milk yield on milk fatty acid composition in Holstein cows. J. Dairy Sci. 88:3886-3893.

Kelsey, J. A., B. A. Corl, R. J. Collier, and D. M. Bauman. 2003. The effect of breed, parity, and stage of lactation on conjugated linoleic acid (CLA) in milk fat from dairy cows. J. Dairy Sci. 86:2588-2597.

Lee, K. W., H. J. Lee, H. Y. Cho, and Y. J. Kim. 2005. Role of the conjugated linoleic acid in the prevention of cancer. Crit. Rev. Food Sci. Nutr. 45:135-144.

Mesa, M. D., G. M. Aguilera, and A. Gil. 2007. Efectos saludables de los lípidos en la dieta. Aliment. Nutr. Salud 14:12-26.

Metka, Z., S. Vekoslava, and I. Rogelj. 2006. Milk fatty acid composition of goats grazing on alpine pasture. Small Rumin. Res. 64:45-52.

Othmane, M. H., L. F. De La Fuente, J. A. Carriedo, and F. San Primitivo. 2002a. Heritability and genetic correlations of test day milk yield and composition, individual laboratory cheese yield, and somatic cell count for dairy ewes. J. Dairy Sci. 85:2692-2698.

Othmane, M. H., L. F. De La Fuente, J. A. Carriedo, and F. San Primitivo. 2002b. Factors affecting test-day milk composition in dairy ewes, and relationships amongst various milk components. J. Dairy Res. 69:53-62.

Peterson, D. G., J. A. Kelsey, and D. E. Bauman. 2002. Analysis of variation in cis-9, trans-11 conjugated linoleic acid (CLA) in milk fat dairy cows. J. Dairy Sci. 85:2164-2172.

SAS Institute. 1997. SAS User's Guide Edition. SAS Inst. Inc., Cary, $\mathrm{NC}$

Soyeurt, H., P. Dardenne, G. Lognay, D. Veselko, P. Mayeres, C. Bertozzi, and N. Gengler. 2006. Variation in fatty acid contents of milk and milk fat within and across breeds. J. Dairy Sci. 89:48584865 .

Soyeurt, H., and N. Gengler. 2008. Genetic variability of fatty acids in bovine milk. Biotechnol. Agron. Soc. Environ. 12:203-210.

Soyeurt, H., A. Gillon, S. Vanderick, P. Mayeres, C. Bertozzi, and N. Gengler. 2007. Estimation of heritability and genetic correlations for the major fatty acids in bovine milk. J. Dairy Sci. 90:44354442.

Stoop, W. M., J. A. M. van Arendonk, J. M. L. Heck, H. J. F. van Valenberg, and H. Bovenhuis. 2008. Genetic parameters for major milk fatty acids and milk production traits of Dutch HolsteinFriesians. J. Dairy Sci. 91:385-394.

Tsiplakou, H., and G. Zervas. 2008. The effect of dietary inclusion of olive tree leaves and grape marc on the content of conjugated linoleic acid and vaccenic acid in the milk of dairy sheep and goats. J. Dairy Res. 75:270-278. 